\title{
Spatial Distribution of Grapes Sugar Content and its Correlations with Climate Characteristics and Climate Suitability in the Huși (Romania) Wine Growing Region
}

\author{
Liviu Mihai IRIMIA ${ }^{1 *}$, Cristian Valeriu PATRICHE², Georgeta Mihaela BUCUR ${ }^{3}$, \\ Hervé QUÉNOL ${ }^{4}$, Valeriu V. COTEA ${ }^{1}$ \\ ${ }^{1}$ University of Agricultural Sciences and Veterinary Medicine, Faculty of Horticulture, 3, Mihail Sadoveanu Alley, Iaşi, 700490, Romania; \\ livirimia@uaiasi.ro (*correspondingauthor);vcotea@uaiasi.ro \\ ${ }^{2}$ Romanian Academy, Iași Branch, Geography Group, 8, Carol I Street, 700505, Iasi, Romania; pvcristi@yahoo.com \\ ${ }^{3}$ University of Agricultural Sciences and Veterinary Medicine, Faculty of Horticulture, 59, Bulevardul Marasti, 011464, \\ Bucharest,_Romania;mihaela_g_savu@yahoo.com \\ ${ }^{4}$ LETG-Rennes (COSTEL), UMR 6554 CNRS, Université Rennes-2, Rue du Recteur Henry le Moal, 35000, Rennes, France; herve.quenol@ubb.fr
}

\begin{abstract}
Previous studies have analyzed mainly the spatial distribution of grapes quality parameters at the plot scale, and concluded that grapes sugar content is a variable parameter, with a less predictable spatio-temporal evolution. Our study aimed to identify a pattern of spatial variation of grapes sugar content at a regional scale, under the temperate continental climate of the Huşi (Romania) wine growing region. In order to do this, grapes sugar content was analyzed in relation to climate. The conditioning of grapes sugar content by climatic factors was analyzed based on regression models (Pearson correlation coefficient, coefficient of determination, linear regression). Spatial variation of grapes sugars content was achieved by the regression - kriging approach, using climate suitability as predictor. Spatial variation of obtainable wine types was achieved by classifying the spatial distribution of grapes sugar content, according to DOC wine production regulation for the Husi area. The study revealed that among climatic factors, the actual sunshine duration is the most influential one on grapes sugar content. Mapping grapes sugar content generated a coherent spatial distribution pattern at the vineyard scale, as it significantly correlates with terrain altitude. Based on grapes sugar content spatial variation, two areas with different potential for sugars accumulation into grapes were delineated. The outcomes reveal that grapes sugar content presents significant correlations with climate variables specific to vineyards and with climate suitability for wine production. Knowing these correlations allows revealing patterns that determine the spatial distribution of the grapes sugar content.
\end{abstract}

Keywords: grapevine, grapes sugar content, spatial distribution, vineyard, wine type

\section{Introduction}

Effective vineyard management and obtaining the targeted wine style require thorough knowledge of spatial variation of chemical compounds which generate grapes quality. They are mainly sugars, organic acids, phenolic compounds and aroma compounds, accumulated in berries during their growth and ripening. Among them, sugars are the most important ones (Huglin, 1986), as they determine the alcoholic content, the balance of taste and the final sensory profile of the wine.

When analyzed at a vine level, in known technological and environmental conditions, grapes sugar content is a rather easy to explore parameter, as it is specific to wine grape varieties and it reacts to viticultural practices (Champagnol, 1984; Galet, 1993). However, when analyzed in relation to its spatial variation within the field, it proves to be, a spatially and temporally variable parameter, difficult to analyze and generating contrasting results. Studies conducted up to date on mapping grapes sugar content conclude that "maps from previous years are not useful in the management of harvest quality in the next year" (Tisseyre et al., 2008), or that "soluble solids had a higher level of uncertainty for being predicted in the field" (Santos et al., 2012). In contrast, Bramley (2005), referring to yield quality considers that "its variation appears to be sufficiently temporally stable to justify the identification of 'quality zones' within vineyards", and also that sugar concentrations "are much less variable than total phenolics concentration". Nonetheless, due to the variability of this parameter and the multitude of factors that influence it, no stable pattern of spatial distribution at vineyard scale has been obtained. 
Spatial variability of grapes sugar content is generated by lack of uniformity of vineyard' topography, soils and climate (Van Leeuwen, 2010), while its temporal variability is caused by vintage climate (Jackson and Lombard, 1993). What is more, grapes sugar content depends on grapevine variety, yield size (Huglin and Balthazard, 1976), vines age (Galet, 1993) and vineyard training system (Huglin, 1978). Therefore, there is a complex conditioning of this parameter, which requires the analysis of its correlations with a large number of biological, environmental and cultural factors in order to understand the patterns driving its spatial distribution.

The methods used to map the spatial distribution of grapes sugar content within the vineyards are not well defined, they implying yet the difficulty of sampling a large amount of berries for a pertinent depiction of the analyzed area. Taking as a model the technologies involved for in real-time anthocyanins content analysis (Lamb et al., 2003), some harvest attached tools based on refractometry and spectrometry were designed (Wold et al. 2001; Workman and Burns 2001; Tisseyre and Taylor, 2005; Sethuramasamyraja et al., 2007) but they are not yet widespread in practice. As an alternative, some authors suggest the use of spatial distribution of the yield size as an indicator, taking into account its correlation with grapes quality indicators (Bramley, 2005), while others consider NDVI (Normalized Difference Vegetation Index) to be a more relevant indicator (Agelet-Fernández et al., 2009).

Unlike previous studies concerning spatial variation of grapes quality parameters at the plot scale (Bramley, 2005; Tisseyre et al., 2008; Trought and Bramley, 2011; Santos et al., 2012), this study analyzes spatial variation of grapes sugar content at the vineyard scale, aiming to reveal a possible model of spatial distribution. So far, grapes sugar content for the 2011 vintage has been analyzed in relation to multiannual averages of the climatic variables specific to the Huşi vineyard, and mapped based on its significant correlation with climatic suitability for wine production generated by them.

\section{Materials and methods}

\section{Study area}

The study area is the Husi wine growing region, located in the eastern part of Romania, at $46^{\circ} 67^{\prime}$ lat. $\mathrm{N}$ and $28^{\circ} 13^{\prime}$ long. E, near the town of Huşi (Fig. 1). It has 2139 ha and includes four vineyards: Schit (554.3 ha); Dobrina (570.6 ha); Corni (264.4 ha); and Recea (749.1 ha). The relief is like an amphitheater with an eastern opening and a decreasing altitude from $300 \mathrm{~m}$ above sea level (asl.) at the western limit to $40 \mathrm{~m}$ asl. at the eastern limit. The Schit and Dobrina vineyards are located above $150 \mathrm{~m}$ asl., on slopes with 10 to $30 \%$ inclination, in the higher and hilly western part; the Recea and Corni vineyards are located below 150 masl., mainly on flat terrains and less inclined slopes, in the lower eastern part of the area. The area is subjected to a temperate continental climate, $\mathrm{Dfb}$ according to World Map of the Köppen-Geiger climate classification updated (Kottek et al., 2006).

\section{Sampling the grapessugar content}

The study refers to grapes sugar content (GrSC) of the 2011 vintage. In order to ensure a representative sampling for the study area, berry samples were taken from different 26 locations (Fig. 1), each of them with a surface of about 1 ha. The geographical coordinates of the 26 sampling sites were established by using GPS. For each sampling site, $\operatorname{GrSC}(\mathrm{g} / \mathrm{L})$ was measured for each of the 'Fetească albă, 'Fetească regală, 'Aligoté' and 'Tămâioasă românească' $V$. vinifera $\mathrm{L}$. wine grape varieties, representing the established wine grape variety assortment. Each wine grape variety was represented by five vines, randomly selected, placed on different rows; from each vine, five berries per cluster were sampled, from four clusters, for a number of 20 berries per vine and 100 berries per variety. To ensure a random sample, the clusters were chosen arbitrarily, without taking into account their size or their location inside the canopy. Also, the berries were sampled from different positions and depths of the cluster. Until they were analyzed in the laboratory, the samples were kept in a freezer, at a temperature of $5{ }^{\circ} \mathrm{C}$. The sugar concentration of grapes was determined in the laboratory, according to OIV protocol (OIV,
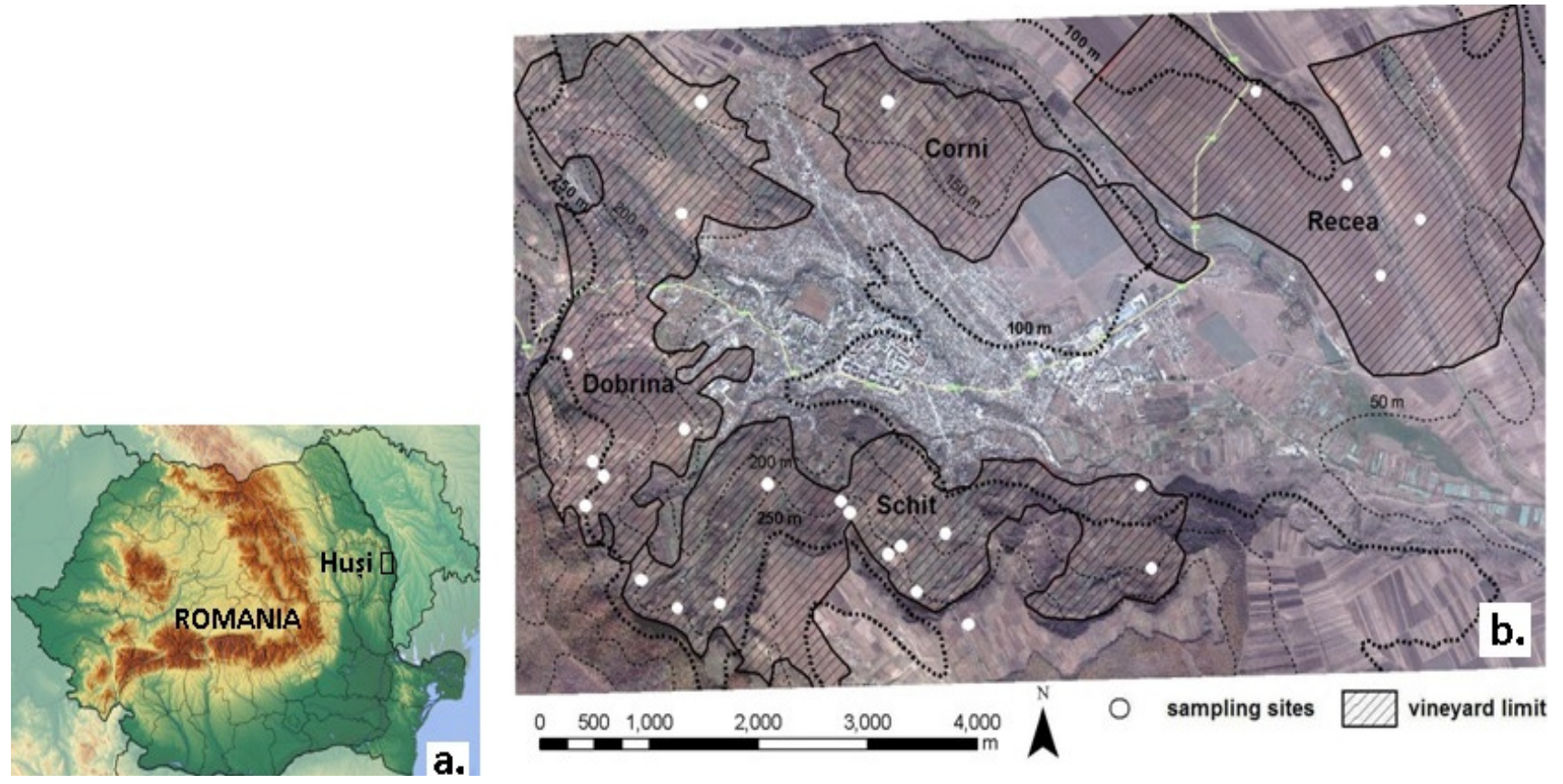

Fig. 1. Location of Huşi wine growing region in Romania (a), its structure and the locations of the 26 sampling sites (b) 
252

1990). To ensure the representativeness of the samples for the sampling sites, the GrSC was expressed as the average of the grapes sugar content for the four wine grape varieties analyzed, thus each of them having equal weight in the berries sample (Table 1). In order to have comparable berries samples, the sampling was carried out in a single day (11 September, 2011), with about $4-5$ days before harvesting, from vines with the same training system (Cazenave; rather 30 shoots per vine; 25 to 30 grapes per vine; 3700 vines per ha).

\section{Analysis of climate variables}

For each of the 26 sampling sites, there were analyzed the values of nine climate variables, which characterize the climate suitability for different types of wine production in temperate continental climate conditions (Irimia et al, 2014): average annual temperature (AAT, ${ }^{\circ} \mathrm{C}$ ); average temperature of the warmest month (TWM, $\left.{ }^{\circ} \mathrm{C}\right)$; global radiation $\left(\mathrm{GR}, \mathrm{kcal} / \mathrm{cm}^{2} / \mathrm{Apr} 1^{\text {st }}\right.$ to Sept 30); actual sunshine duration (ASD, hours/Apr $1^{\text {st }}$ to Sept 30); precipitation in the growing season (PP, mm/Apr $1^{\text {tt }}$ to Sept 30); sum of effective temperatures $\left(\sum \mathrm{t}_{\mathrm{u}}{ }^{\circ} \mathrm{C} / \mathrm{Apr} 1^{\mathrm{t}}\right.$ to Sept 30); actual heliothermal index (IHa/Apr $1^{\text {st }}$ to Sept 30); bioclimatic index (Ibcv/Apr $1^{\mathrm{st}}$ to Sept 30) and oenoclimate aptitude index (IAOe/Apr $1^{\text {st }}$ to Sept 30) (Table 1). The values of climate variables for each sampling site were extracted from their spatial distributions in the Huşi wine growing region (Irimia et al., 2011), previously established based on multiannual averages (1961-2000) of temperature and precipitation altitudinal gradients implemented in NewLocClim software (FAO, 2003), and on values derived from DEM for the global radiation and sunshine duration (Patriche, 2007).

\section{Analysis of climate suitability for wine production}

Climate suitability was assessed in a previous phase of the study based on multiannual averages (1961-2000) of ten climate variables characterizing the Husi wine growing region (Irimia et al., 2014). Each climate variable was mapped, and its values classified and ranked with 5 to 10 points, according to their suitability for wine production. Then the maps were combined in a GIS database, were georeferenced and the average of ranking points was computed at the pixel level $(30 \times 30 \mathrm{~m})$. The average of ranking points (a.r.p.) expresses climate suitability and varies between 5 and 10 with the following significance: 5 a.r.p. $=$ climate suitability for white table wines, sparkling wines and wines for distillates; 6 a.r.p. $=$ climate suitability for white table wines, sparkling wines, and wines for distillates, as well as for quality white wines in very suitable years, in terms of climate; 7 a.r.p.= climate suitability for quality white wines; 8 a.r.p. = climate suitability primarily for quality white wines and secondarily for red table wines; 9 a.r.p. = climate suitability primarily for quality red wines and secondarily for quality white wines; 10 ar.. . $=$ climate suitability for quality red wines.

Analysis of the relationships between climate variables and GrSC was performed by computing regression models (Pearson correlation coefficient; coefficient of determination; linear regression) between the GrSC and the multiannual means of the nine climate variables characterizing each of the 26 sampling sites. The results were assessed according to the statistical significance of the linear regression model for a significance level of 0.05 . This analysis aimed to highlight the factors driving the GrSC and also to reveal the extent to which they influence this grapes quality parameter.
Analysis of the relationships between climate suitability and GrSC was performed based on the same previously used regression models (Pearson correlation coefficient; coefficient of determination; linear regression) this time computed between the GrSC and the average ranking points (a.r.p.) revealing the climate suitability of each of 26 sampling sites. The results were also assessed according to statistical significance of the linear regression model for a significance level of 0.05 . This analysis aimed to reveal the conditioning of the GrSC by local climate suitability.

Spatial distribution of GrSC within the vineyard was achieved based on its significant correlation with local climate suitability revealed by the regression models computed in the previous phase. The spatialization method was the linear regression by using climate suitability as predictor, followed by ordinary kriging of regression residuals. Subsequently, the regression and kriging spatial models were added up in order to achieve the final estimated continuous distribution of GrSC. Interpretation of results is based on: statistical analysis (Min, Max, Range, CV, STD); analysis of the "spread" index, respective the difference between the maximum and minimum values expressed as a $\%$ of the median value (Bramley, 2005); and analysis of the correlation between the GrSC and the altitude.

Spatial distribution of wine types which can be obtained in accordance with the GrSC for the 2011 vintage was achieved by classifying the spatial distribution of GrSC under the regulations of DOC wine production for the Huşi wine growing region (ONIV). In addition to the requirements regarding the geographical location, wine grape variety, technological parameters of plantation and yield size, this regulation imposes a minimum content of sugar in the berries at the harvest moment, as follows: a GrSC higher than 170 $\mathrm{g} / \mathrm{L}$, up to $190 \mathrm{~g} / \mathrm{L}$ is needed to produce quality wines with geographical denomination (IG); a GrSC higher than 190 $\mathrm{g} / \mathrm{L}$ up to $196 \mathrm{~g} / \mathrm{L}$ is required to produce high quality wines with controlled designation of origin (DOC); a GrSC higher than $196 \mathrm{~g} / \mathrm{L}$ up to $213 \mathrm{~g} / \mathrm{L}$ is needed to produce controlled designation of origin wines harvested at full maturity (DOCCMD); a GrSC higher than $213 \mathrm{~g} / \mathrm{L}$ is needed to produce controlled designation of origin wines late harvest (DOC$\mathrm{CT}$ ).

\section{Results}

\section{Climatic variables}

According to the estimates of the nine climatic variables corresponding to the 26 sampling sites, the Schit and Dobrina vineyards from the higher and hilly western part are characterized as poor in heliothermic resources and wetter, while the Corni and Recea vineyards from the lower and plain part as richer in heliothermal resources and slightly less humid (Table 1). Thermal parameters record minimum values in the Dobrina vineyard $\left(\mathrm{AAT}=9.0^{\circ} \mathrm{C}\right.$; $\mathrm{TWM}=$ $20.4^{\circ} \mathrm{C} ; \Sigma \mathrm{tu}=1203.4^{\circ} \mathrm{C}$ ) and maximum ones in the Recea vineyard $\left(\mathrm{AAT}=10.1^{\circ} \mathrm{C} ; \mathrm{TWM}=21.7^{\circ} \mathrm{C} ; \Sigma \mathrm{tu}=1427.1\right.$ $\left.{ }^{\circ} \mathrm{C}\right)$. In a sampling site of the Schit vineyard, thermal parameters record absolute maximum values for the Huşi wine growing region $\left(\mathrm{AAT}=10.2^{\circ} \mathrm{C} ; \mathrm{TWM}=21.8^{\circ} \mathrm{C} ; \Sigma\right.$ tu $=1449.0^{\circ} \mathrm{C}$ ), but they are not representative for this 
Table 1 . The values of climate variables, climate suitability and grapes sugar content (GrSC, $\mathrm{g} / \mathrm{L}$ ) characterizing the 26 sampling sites from the Huşi wine growing region

\begin{tabular}{|c|c|c|c|c|c|c|c|c|c|c|c|c|c|c|c|}
\hline \multirow{3}{*}{$\begin{array}{l}\text { Sampling } \\
\text { sites }\end{array}$} & \multirow{3}{*}{ Vineyard } & \multirow{3}{*}{ Altitude } & \multirow{3}{*}{ Aspect } & \multicolumn{9}{|c|}{ Climatevariables* } & \multirow{2}{*}{\multicolumn{2}{|c|}{$\begin{array}{c}\text { Climatesuitability } \\
\text { (ar.p.) }\end{array}$}} & \multirow{3}{*}{$\begin{array}{c}\mathrm{GrSC}(\mathrm{g} / \mathrm{L}) \\
\text { site }\end{array}$} \\
\hline & & & & \multirow{2}{*}{$\begin{array}{l}\text { AAT } \\
\left({ }^{\circ} \mathrm{C}\right)\end{array}$} & \multirow{2}{*}{$\begin{array}{l}\text { TWM } \\
\left({ }^{\circ} \mathrm{C}\right)\end{array}$} & \multirow{2}{*}{$\begin{array}{l}\sum \mathrm{ut} \\
\left({ }^{\circ} \mathrm{C}\right)\end{array}$} & \multirow{2}{*}{$\begin{array}{c}\text { ASD } \\
\text { (hours) }\end{array}$} & \multirow{2}{*}{$\begin{array}{c}\mathrm{GR} \\
\left(\mathrm{kcal} / \mathrm{cm}^{2}\right)\end{array}$} & \multirow{2}{*}{$\begin{array}{c}\mathrm{PP} \\
(\mathrm{mm})\end{array}$} & \multirow{2}{*}{ IAOe } & \multirow{2}{*}{ Ibcr } & \multirow{2}{*}{$\mathrm{IHa}$} & & & \\
\hline & & & & & & & & & & & & & site & vineyard & \\
\hline 1 & Schit & 60.1 & $\mathrm{~N}$ & 10.2 & 21.8 & 1449.0 & 1461.6 & 87.9 & 342.2 & 4702.9 & 7.8 & 2.1 & 9.4 & \multirow{13}{*}{8.0} & 228.9 \\
\hline 2 & Schit & 161.3 & NV & 9.6 & 21.2 & 1333.3 & 1383.3 & 83.3 & 353.9 & 4447.8 & 6.8 & 1.8 & 8.0 & & 190.0 \\
\hline 3 & Schit & 129.3 & $\mathrm{NE}$ & 9.8 & 21.4 & 1369.6 & 1383.3 & 85.9 & 350.2 & 4503.6 & 7.0 & 1.9 & 8.3 & & 209.8 \\
\hline 4 & Schit & 211.8 & $\mathrm{NE}$ & 9.4 & 20.8 & 1276.5 & 1383.3 & 79.4 & 359.7 & 4359.8 & 6.5 & 1.8 & 7.0 & & 194.6 \\
\hline 5 & Schit & 236.9 & $\mathrm{~N}$ & 9.2 & 20.7 & 1248.5 & 1479.0 & 88.3 & 362.6 & 4411.9 & 6.8 & 1.8 & 8.3 & & 217.3 \\
\hline 6 & Schit & 205.0 & NV & 9.4 & 20.9 & 1284.1 & 1470.3 & 81.3 & 358.9 & 4458.6 & 6.9 & 1.9 & 8.1 & & 223.8 \\
\hline 7 & Schit & 196.1 & NV & 9.4 & 20.9 & 1294.0 & 1435.5 & 81.9 & 357.9 & 4439.3 & 6.8 & 1.9 & 7.8 & & 198.0 \\
\hline 8 & Schit & 202.5 & $\mathrm{~V}$ & 9.4 & 20.9 & 1286.9 & 1383.3 & 89.1 & 358.6 & 4376.0 & 6.5 & 1.8 & 8.3 & & 211.5 \\
\hline 9 & Schit & 198.8 & V & 9.4 & 20.9 & 1291.0 & 1287.6 & 89.5 & 358.2 & 4286.7 & 6.1 & 1.7 & 7.7 & & 190.6 \\
\hline 10 & Schit & 219.5 & $\mathrm{~N}$ & 9.3 & 20.8 & 1267.9 & 1322.4 & 80.6 & 360.6 & 4285.6 & 6.2 & 1.7 & 6.9 & & 179.7 \\
\hline 11 & Schit & 207.4 & SE & 9.4 & 20.9 & 1281.4 & 1374.6 & 92.3 & 359.2 & 4358.9 & 6.5 & 1.8 & 8.0 & & 205.7 \\
\hline 12 & Schit & 201.2 & $\mathrm{NE}$ & 9.4 & 20.9 & 1288.3 & 1418.1 & 85.5 & 358.5 & 4413.1 & 6.7 & 1.8 & 8.1 & & 231.8 \\
\hline 13 & Schit & 198.1 & $\mathrm{NE}$ & 9.4 & 20.9 & 1291.8 & 1400.7 & 84.3 & 358.1 & 4401.1 & 6.6 & 1.8 & 8.1 & & 209.3 \\
\hline 14 & Dobrina & 263.7 & $\mathrm{E}$ & 9.1 & 20.5 & 1218.8 & 1365.9 & 89.0 & 365.7 & 4252.5 & 6.1 & 1.7 & 7.4 & \multirow{7}{*}{7.9} & 173.0 \\
\hline 15 & Dobrina & 277.7 & E & 9.0 & 20.4 & 1203.4 & 1383.3 & 88.7 & 367.3 & 4245.6 & 6.1 & 1.7 & 7.4 & & 195.6 \\
\hline 16 & Dobrina & 276.7 & E & 9.0 & 20.4 & 1204.5 & 1383.3 & 88.9 & 367.2 & 4247.4 & 6.1 & 1.7 & 7.4 & & 202.8 \\
\hline 17 & Dobrina & 182.8 & E & 9.5 & 21.0 & 1309.0 & 1400.7 & 88.6 & 356.4 & 4427.6 & 6.7 & 1.8 & 8.5 & & 214.8 \\
\hline 18 & Dobrina & 215.7 & $\mathrm{E}$ & 9.3 & 20.8 & 1272.1 & 1392.0 & 91.8 & 360.2 & 4361.7 & 6.5 & 1.8 & 8.0 & & 220.5 \\
\hline 19 & Dobrina & 158.5 & SV & 9.6 & 21.2 & 1336.5 & 1287.6 & 92.6 & 353.6 & 4356.9 & 6.3 & 1.7 & 8.5 & & 209.4 \\
\hline 20 & Dobrina & 161.2 & $S$ & 9.6 & 21.2 & 1333.3 & 1392.0 & 90.6 & 353.9 & 4456.5 & 6.8 & 1.9 & 8.5 & & 212.1 \\
\hline 21 & Corni & 157.2 & $S$ & 9.7 & 21.2 & 1337.9 & 1374.6 & 92.0 & 353.4 & 4446.2 & 6.7 & 1.8 & 8.5 & \multirow[t]{2}{*}{8.5} & 219.0 \\
\hline 22 & Recea & 104.1 & SV & 9.9 & 21.5 & 1398.3 & 1487.7 & 90.3 & 347.3 & 4651.9 & 7.6 & 2.1 & 9.0 & & 221.4 \\
\hline 23 & Recea & 89.3 & $\mathrm{E}$ & 10.0 & 21.6 & 1415.3 & 1409.4 & 90.1 & 345.6 & 4599.6 & 7.3 & 2.0 & 8.9 & \multirow{4}{*}{9.0} & 220.3 \\
\hline 24 & Recea & 83.4 & $S$ & 10.0 & 21.7 & 1422.1 & 1470.3 & 90.7 & 344.9 & 4670.8 & 7.7 & 2.1 & 9.4 & & 217.6 \\
\hline 25 & Recea & 79.1 & SV & 10.1 & 21.7 & 1427.1 & 1383.3 & 91.2 & 344.4 & 4591.3 & 7.2 & 2.0 & 8.9 & & 213.6 \\
\hline 26 & Recea & 80.2 & SV & 10.1 & 21.7 & 1425.8 & 1392.0 & 90.7 & 344.5 & 4598.1 & 7.3 & 2.0 & 8.9 & & 197.3 \\
\hline
\end{tabular}

${ }^{*} \mathrm{AAT}=$ average annual temperature $\left({ }^{\circ} \mathrm{C}\right) ; \mathrm{TWM}=$ average temperature of the warmest month $\left({ }^{\circ} \mathrm{C}\right) ; \sum \mathrm{t}_{\mathrm{u}}=$ sum of effective temperatures $\left({ }^{\circ} \mathrm{C} / \mathrm{Apr} 1^{\text {st }}\right.$ to Sept $30) ; \mathrm{ASD}=$ actual sunshine duration (hours $/$ Apr $1^{\text {st }}$ to Sept 30); GR = global radiation $\left(\mathrm{kcal} / \mathrm{cm}^{2} / \mathrm{Apr} 1^{\text {st }}\right.$ to Sept 30); PP = precipitation in the growing season $\left(\mathrm{mm} / \mathrm{Apr} 1^{\text {st }}\right.$ to Sept 30); IAOe = oenoclimate aptitude index (Apr $1^{\text {st }}$ to Sept 30); Ibcv = bioclimatic index; IHa $=$ actual heliothermal index $\left(\right.$ Apr $1^{\text {st }}$ to Sept 30$)$ (Apr $1_{\text {st }}$ to Sept 30); (Irimia et al., 2014).

vineyard, as for all the other 12 sampling sites from this area the thermal parameters are much lower (Table 1).

GR values are the highest in the sampling sites from the Dobrina, Corni and Recea vineyards $\left(90.1-92.0 \mathrm{kcal} / \mathrm{cm}^{2}\right)$, which are exposed mainly to south and east, and the lowest in the sampling sites from Schit $\left(80.6-87.9 \mathrm{kcal} / \mathrm{cm}^{2}\right)$, exposed mainly to north (Table 1). ASD varies significantly in the Schit and Dobrina vineyards located on uneven relief and are much homogeneous on the flat terrains of the Recea vineyard; overall, the sampling sites from Recea are characterized by values of about 1400 hours (1383.3-1487.7 hours), while those of the Schit, Dobrina and Corni present very dissimilar values, ranging, in a large interval, from 1287.6 to 1479.0 hours. PP values vary in a narrower range, from $342.2 \mathrm{~mm}$ to $367.3 \mathrm{~mm}$, with minimum values in the sampling sites from Recea and maximum ones in those from Dobrina and Schit (Table 1). The bioclimatic indices IAOe, $\mathrm{Ibcv}$ and IHa reveal poor heliothermal resources in the sampling sites from Dobrina and Schit, and maximums in the sampling sites from Recea and Corni, thus revealing enhanced heliothermal resources (Table 1).

\section{Climate suitability}

The estimates of climate suitability for wine production of the 26 sampling sites vary between 6.9 a.r.p. and 9.4 a.r.p. (Table 1). It is a wide range of variation that shows climatic resources suitable for the production of different types of wine, from sparkling wines to quality red wines. However, the overall averages of the Schit and Dobrina vineyards of the higher zone are of 8.0 a.r.p. and 7.9 a.r.p. respectively, indicating climatic suitability for quality white wines and red table wines; the overall averages of the Corni and Recea vineyards of the lower zone are higher, by 8.6 a.r.p. and 9.0 a.r.p. respectively, revealing the climate suitability for quality red wines production primarily and quality white wines production in secondary.

\section{Correlations between climate variables and GrSC}

The analysis of the correlation coefficients between the estimates of climate variables and the GrSC for the 26 sampling sites, reveals the climatic variables driving GrSC, the way they influence GrSC and their representativity in the assessment of the spatial variation of GrSC.

The Pearson correlation coefficient ranging from 0.28 to 0.60 shows the conditioning of GrSC by the local climatic factors (Fig. 2a to Fig. 2i). Climatic conditioning of GrSC is best represented by IHa, Ibcv and IAOe $(r=0.57-0.60)$ (Fig. $2 \mathrm{a}, 2 \mathrm{~b}, 2 \mathrm{c}$ ). The climatic factor which is most influential in GrSC is ASD which strongly correlates with the GrSC ( $r=$ 0.57 ) while the least influential is GR which weakly correlates with GrSC ( $\mathrm{r}=0.28)$ (Fig. 2g). The temperature, characterized by AAT, TWM and $\mathrm{tu}$ (Fig. 2d, 2e, 2f), as well as the PP, moderately correlate with GrSC $(r=0.43)$. All correlations are significant for $\mathrm{p}<0.05$, except for the one for the GR.

The coefficient of determination $\left(\mathrm{R}^{2}\right)$ reveals that of all climatic factors, the ASD explains best, rather $33 \%$ of the GrSC variance (Fig. 2h), while temperature (AAT, TWM, $\Sigma \mathrm{tu}$ ) and PP explain only $18 \%$ of the GrSC variance (Fig. 2d, $2 \mathrm{e}, 2 \mathrm{f}, 2 \mathrm{i}$ ).

The simple linear regression shows that, except for PP, the increase of all the other climate variables is associated with the increase of the GrSC (Fig. 2). For the climatic factors, which vary from one year to another, the increase by one unit of the multiannual mean is associated with the increase of GrSC by: 
254
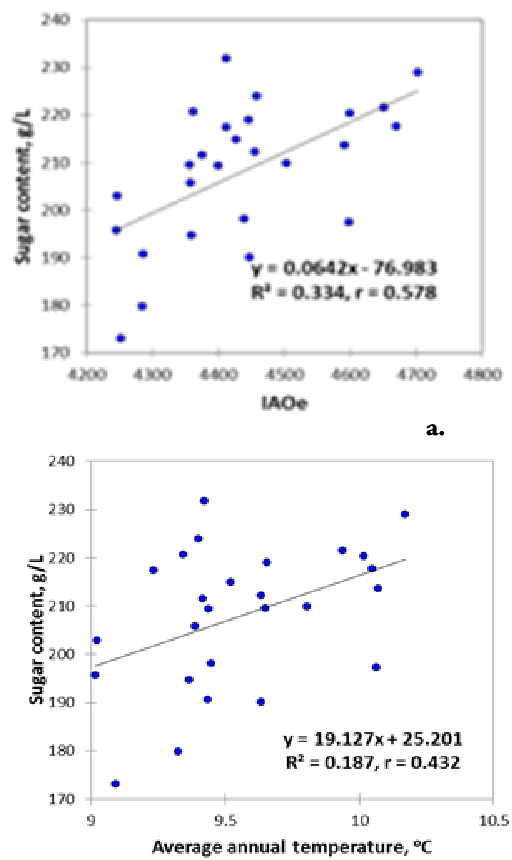

d.

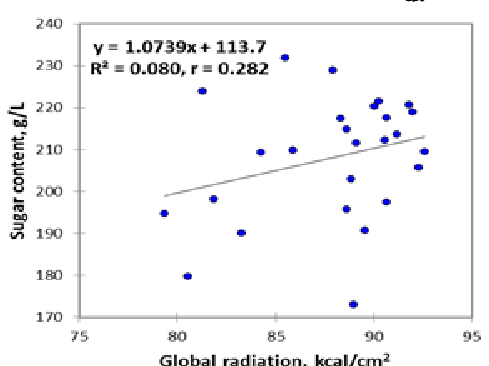

g.
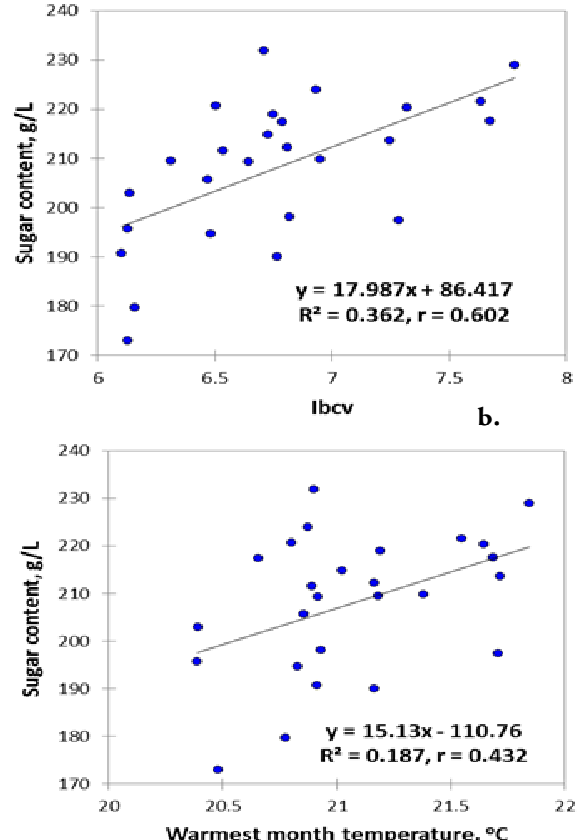

e.

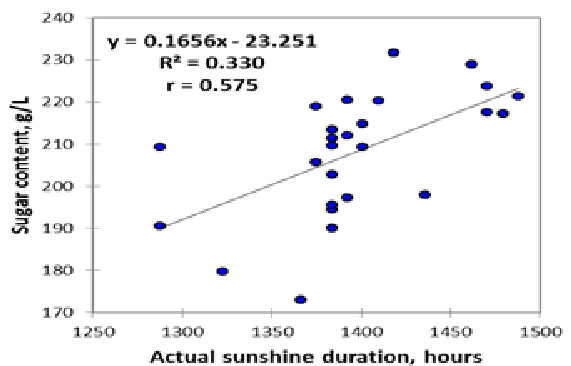

h.

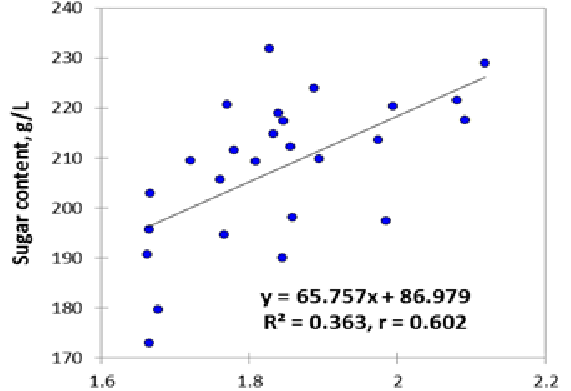

c.
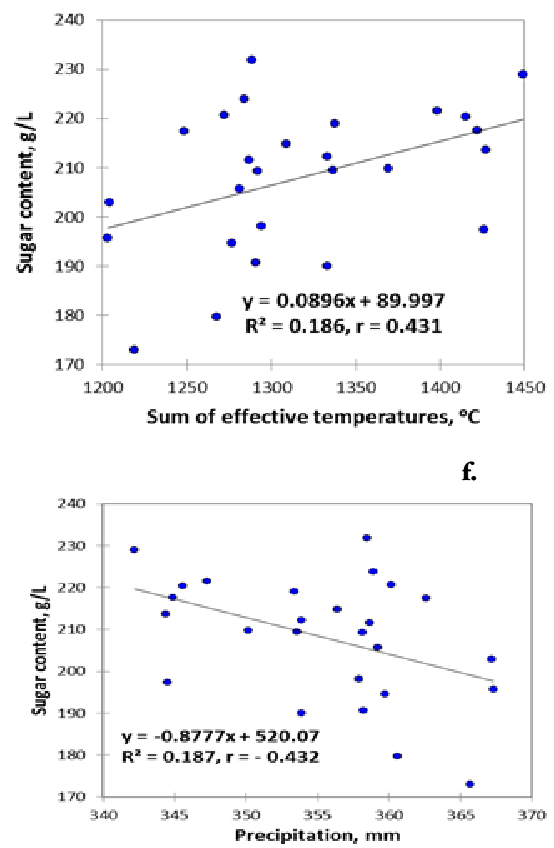

i.

Fig. 2. Regressions between multiannual climate variables and $\mathrm{GrSC}(\mathrm{g} / \mathrm{L})$ for the 2011 vintage in the Huşi wine growing region
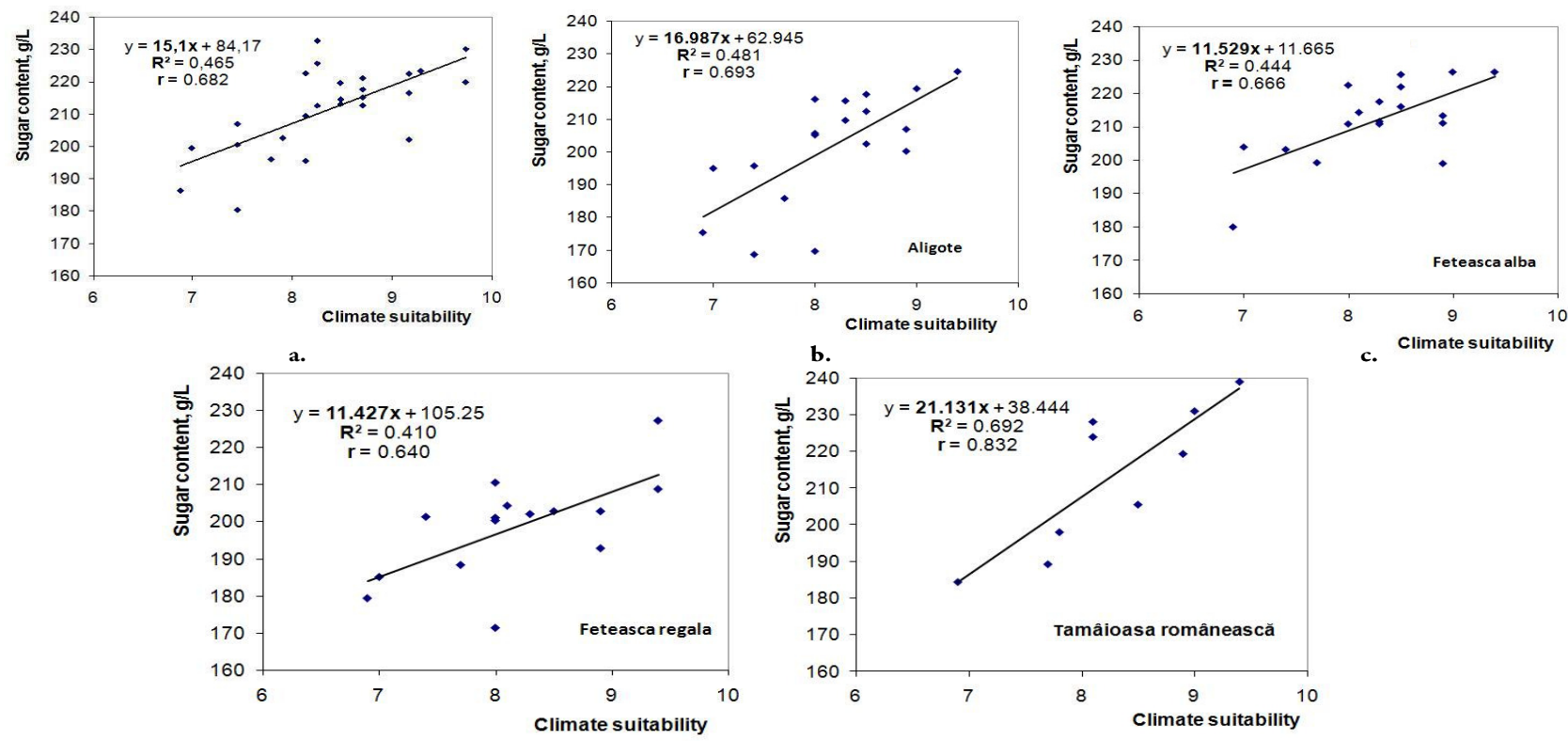

c. Climate suitability

d.

Fig. 3. Regressions between climate suitability for different types of wine production and the GrSC $(\mathrm{g} / \mathrm{L})$ for the 2011 vintage in the Huşi wine growing region: a. for the mean of GrSC on 26 sampling sites; b. for 'Aligoté' variety; c. for 'Fetească albă' variety; d. for 'Fetească regală' variety; e. for 'Tămâioasă românească’ variety 
$19.12 \mathrm{~g} / \mathrm{L}$ in the case of AAT (Fig. 2d); $15.13 \mathrm{~g} / \mathrm{L}$ in the case of TWM (Fig. 2e); $1.07 \mathrm{~g} / \mathrm{L}$ in the case of GR (Fig. 2g); and $0.16 \mathrm{~g} / \mathrm{L}$ in the case of ASD (Fig. $2 \mathrm{~h}$ ). For the PP, the increase by $1 \mathrm{~mm}$ of the multiannual mean is associated with the decrease by $0.87 \mathrm{~g} / \mathrm{L}$ of the GrSC (Fig. 2i).

\section{Correlations between climate suitability and GrSC}

Pearson correlation coefficient reveals a strong positive relationship $(r=0.68)$ between the climate suitability and the GrSC (Fig. 3a); what is more the $\mathrm{R}^{2}$ shows that climate suitability explains $46.5 \%$ of the GrSC variance, and the increase by one unit of the climate suitability/a.r.p. is associated with the increase by $15.1 \mathrm{~g} / \mathrm{L}$ of the GrSC. These correlations are significant for $\mathrm{p}<$ 0.05 .

When it comes to wine grape variety some differences can be noticed: Pearson correlation coefficient $(\mathrm{r})$ ranges between 0.64 (strong positive correlation) for the 'Fetească regală' variety and 0.83 (very strong positive correlation) for the "Tămâioasă românească variety (Fig. 3); the $\mathrm{R}^{2}$ shows that climate suitability explains $41 \%$ of the GrSC variance for the 'Fetească regală variety up to $69 \%$ for the 'Tămâioasă românească variety. The increase by one unit of the climate suitability is associated with the increase of the $\mathrm{GrSC}$ from $11.4 \mathrm{~g} / \mathrm{L}$ for the 'Fetească regală' variety up to 21.1 g/L for the 'Tămâioasă românească variety (Fig. 3).

\section{Spatial variation of the GrSC}

The map of GrSC for the 2011 vintage shows that it ranges between a maximum of $227.5 \mathrm{~g} / \mathrm{L}$ in the Recea vineyard and a minimum of $165.3 \mathrm{~g} / \mathrm{L}$ in the Dobrina and Schit vineyards (Fig. 4). This spatial variation reveals the correlation of GrSC with altitude $\left(r=0.42 ; R^{2}=0.18\right)$, and the altitudinal decrease of the GrSC, from the lower zone towards the higher zone of the study area. The linear regression between the altitude and the GrSC shows that the increase by one $\mathrm{m}$ of the altitude is associated with the decrease by $0.10 \mathrm{~g} / \mathrm{L}$ of the GrSC (Fig. 5), a difference of about $21 \mathrm{~g} / \mathrm{L}$ for the 2011 vintage between the lowermost sampling point $(60.1 \mathrm{~m}$ asl.) and the uppermost sampling point $(277.7 \mathrm{~m}$ asl.).

Statistical data show that the means of the interpolated GrSC values for the study area vary in a narrow range, between $205.9 \mathrm{~g} / \mathrm{L}$ for the Schit vineyard and $216.9 \mathrm{~g} / \mathrm{L}$ for the Recea vineyard (Table 2). The most uniform in terms of GrSC spatial distribution and hence in terms of grapes quality spatial distribution is the Corni vineyard $(\mathrm{CV}=1.2)$, while the less uniform is the Schit vineyard (CV= 4.3). The spread index

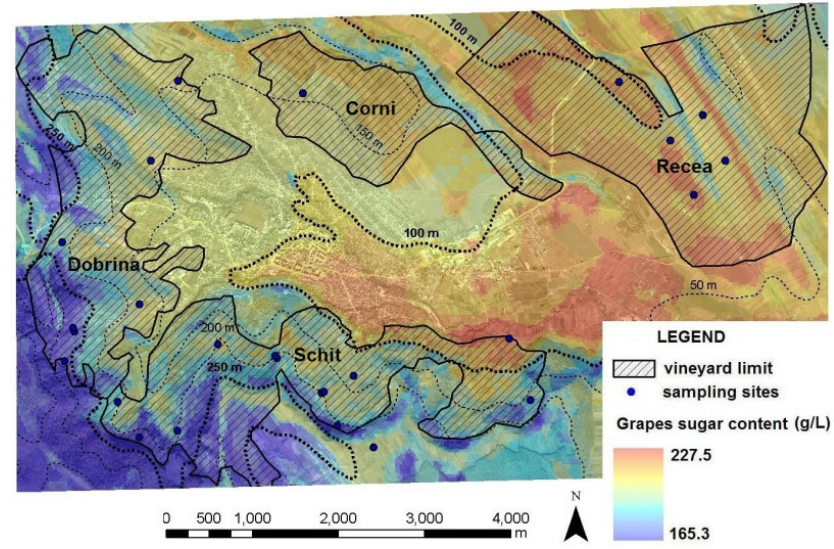

Fig. 4. Spatial distribution of GrSC (g/L) for the 2011 vintage in the Huşi wine growing region

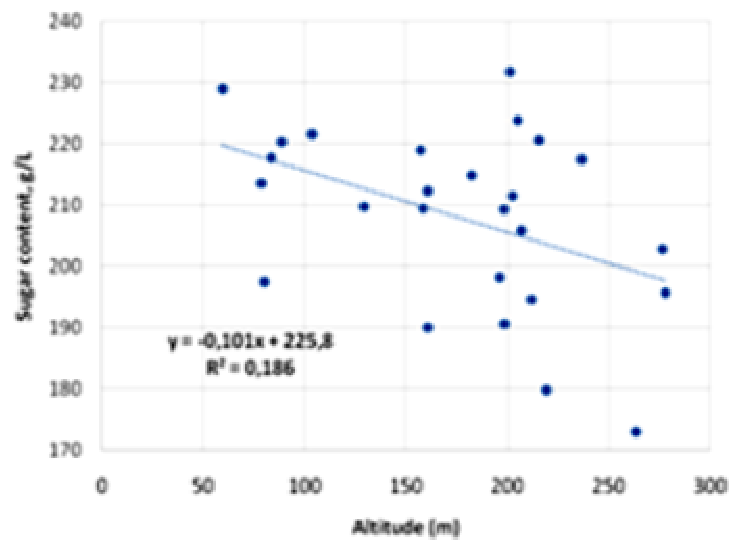

Fig. 5. Regressions between altitude and GrSC (g/L) for the 2011 vintage in the Huşi wine growing region

reveals the same variability: a spread by $7.6 \%$ for the Corni vineyard and by $27.9 \%$ for the Schit vineyard, with an overall average by $16.9 \%$ for the entire study area.

Spatial distribution of wine types which can be obtained depending on spatial distribution of GrSC of 2011 vintage

By classifying the spatial distribution of GrSC of the 2011 vintage according to ranges of GrSC required by the DOC wine production regulation for the Huşi region, it can be noticed that it allows obtaining mainly two types of wine: DOC-CT wine on $52 \%$ of the wine growing region surface and DOC-CMD wine on $41.0 \%$ of the wine growing region surface (Table 3); the GrSC adequate to DOC and IG wines production had insignificant shares, of $3.9 \%$ and $2.8 \%$ respectively of wine growing region area.

The analysis of spatial distribution of GrSC classified according to DOC wine production requirement reveals that the wines types obtainable differentiate according to terrain altitude (Fig. 6): the DOC-CT wine production area extends in the lower zone, up to $150 \mathrm{~m}$ asl.; the DOCCMD wine production area stands between $150-250 \mathrm{~m}$ asl.; the DOC and IG wine production zones correspond to high areas at above $250 \mathrm{~m}$ asl.

Table 2. Statistics for the spatial distribution of the GrSC within the Huşi wine growing region

\begin{tabular}{lcccccccc}
\hline \multirow{2}{*}{ Vineyard } & \multirow{2}{*}{ Surface (ha) } & \multicolumn{7}{c}{ Sugar content $(\mathrm{g} / \mathrm{L})$} \\
\cline { 3 - 9 } & & Min & Max & Range & Mean & STD & CV & Spread $^{*}$ \\
\hline Schit & 554.3 & 168.5 & 226.1 & 57.6 & 205.9 & 8.8 & 4.3 & 27.9 \\
Dobrina & 570.6 & 172.6 & 214.5 & 41.9 & 206.2 & 7.9 & 3.8 & 20.3 \\
Corni & 264.4 & 204.6 & 220.9 & 16.3 & 215.0 & 2.6 & 1.2 & 7.6 \\
Recea & 749.7 & 199.8 & 225.6 & 25.7 & 216.9 & 3.9 & 1.8 & 11.8 \\
\hline * spread is the difference between the maximum and minimum values, expressed as
\end{tabular}
a $\%$ of the mean value (Bramley, 2005).

Table 3. The structure of wine types which can be obtained in the Huşi wine growing region, depending on spatial distribution of GrSC for the 2011 vintage

\begin{tabular}{|c|c|c|c|c|c|c|c|c|c|c|c|}
\hline \multirow{3}{*}{$\begin{array}{c}\text { GrSC } \\
(\mathrm{g} / \mathrm{L})\end{array}$} & \multirow{3}{*}{ Wine type* } & \multicolumn{8}{|c|}{ Vineyard } & \multirow{2}{*}{\multicolumn{2}{|c|}{$\begin{array}{l}\text { Total } \\
\text { surface }\end{array}$}} \\
\hline & & \multicolumn{2}{|c|}{ Schit } & \multicolumn{2}{|c|}{ Dobrina } & \multicolumn{2}{|c|}{ Corni } & \multicolumn{2}{|c|}{ Recea } & & \\
\hline & & ha & $\%$ & ha & $\%$ & ha & $\%$ & ha & $\%$ & ha & $\%$ \\
\hline$<190$ & IG & 35.3 & 6.3 & 26.6 & 4.6 & 0.0 & 0.0 & 0.0 & 0.0 & 62.0 & 2.8 \\
\hline $190-196$ & DOC & 39.6 & 7.1 & 44.2 & 7.7 & 0.0 & 0.0 & 0.0 & 0.0 & 83.9 & 3.9 \\
\hline $196-213$ & $\begin{array}{l}\text { DOC- } \\
\text { CMD }\end{array}$ & 387.8 & 69.9 & 356.6 & 62.4 & 34.8 & 13.1 & 99.3 & 13.2 & 878.6 & 41.0 \\
\hline$>213$ & DOC-CT & 91.4 & 164 & 143.1 & 25.0 & 229.5 & 86.8 & 650.3 & 86.7 & 1114 & 520 \\
\hline & otal & 554.3 & 100 & 570.6 & 100 & 264.4 & 100 & 749.7 & 100 & 2139 & 100 \\
\hline
\end{tabular}


256

Comparing the spatial distributions of wine types which can be obtained (Fig. 6) and climate suitability specific to the Husi area (Fig. 7), a similitude of two spatial distributions can be noticed. Supported by the strong

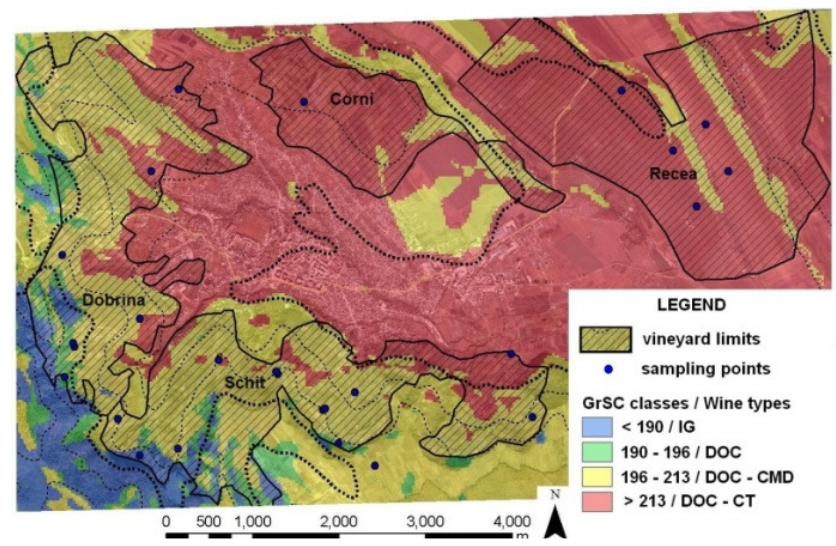

Fig. 6. Spatial distribution of the wine types obtainable within the Husi area according to spatial distribution of the GrSC for the 2011 vintage

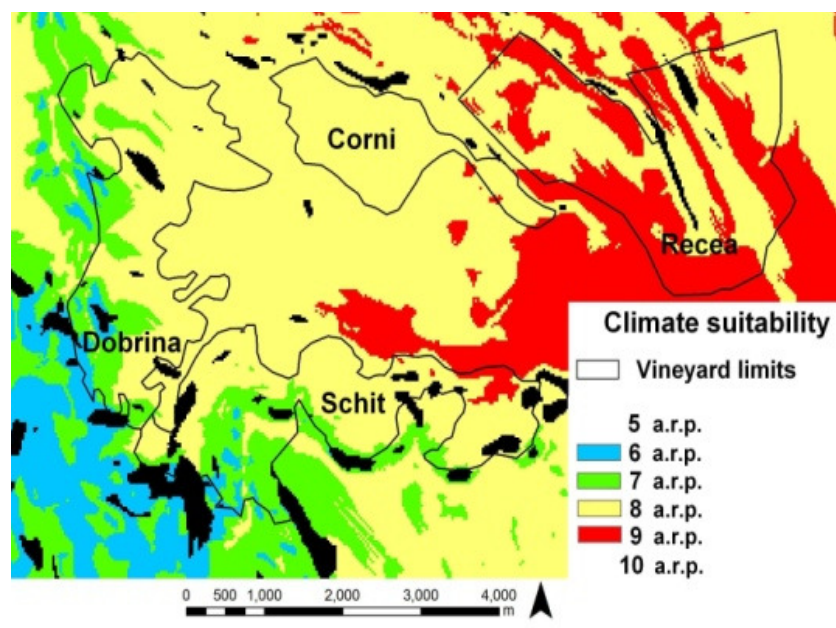

Fig. 7. Map of climate suitability (a.r.p. distribution) within the Husi wine growing region (Irimia et al., 2014)

correlation of GrSC with climate suitability $(r=0.68)$ this similarity may reveal a pattern driving the spatial distribution of $\mathrm{GrSC}$ within the Husi wine growing region.

\section{Discussions}

This study analyzed the correlations of the GrSC of the 2011 vintage with the averages of climate variables characterizing the Huşi wine growing region and also with the climate suitability for wine production they generate. Based on regression - kriging analysis, the spatial distribution of GrSC of the 2011 vintage was developed, and by its classification, the map of wine types which GrSC provides was achieved. The two maps show a potential pattern of spatial distribution of GrSC at the vineyard level. This may be a new result given the fact that the research which has been conducted so far (Bramley, 2005; Tisseyre et al., 2008; Santos et al., 2012) has focused mainly on spatial variation of grapes quality parameters at plot scale. Although the analysis at the plot scale provides very accurate results, it reveals only local distribution patterns generated by the soil influence, while at vineyard scale the factor driving the variability is the climate (Van Leeuwen, 2010).

The study revealed strong correlations, statistically significant for $\mathrm{p}<0.05$, between multiannual averages of climate variables which define the climate of the Huși wine growing region and the GrSC of the 2011 vintage. The ASD, which closely correlates with $\mathrm{GrSC}(\mathrm{r}=0.57)$ turned out to be a very influential climatic factor of the GrSC. These results are in accordance with the ones of previous studies (Teodorescu et al., 1987) emphasizing that the years with an exceeding of ASD of $8.9 \%$ are suitable for wine quality, while those with a deficit of ASD of $9.8 \%$ are unsuitable for wine quality. Temperature, whose influence was expressed in this study by AAT, TWM and $\Sigma$ tu variables, slightly correlates with GrSC $(r=0.43)$; although this correlation is weaker compared to the values communicated by Huglin (1978) $(r=$ $0.71-0.83$ ), it indicates that the temperature should be taken into account when analyzing and modelling the spatial distribution of GrSC.

The close correlation $(\mathrm{r}=0.68)$ between the GrSC for the 2011 vintage and climate suitability of the Huşi wine growing region, identified in our research, reveals one of the relations of yield quality dependence which functions at vineyard level. Climate, together with grapevine variety determine differences of grapes composition at regional level (Van Leeuwen, 2010). Climate also determines the type of wine specific to a certain vineyard (Jones et al., 2005). However, the study revealed that the correlation GrSC - climate suitability has a distinct value for each wine grape variety. This requires a customization of the analysis and modelling of the GrSC for each wine grape variety.

Mapping the GrSC based on its correlation with climate suitability $(\mathrm{r}=0.68)$ revealed a coherent pattern of spatial variation at vineyard level. The study showed a significant correlation of the GrSC with altitude $(r=0.42, p<0.05)$ and that under temperate continental climate conditions of the Huşi wine growing region, an increase by $1 \mathrm{~m}$ of the altitude, is associated with a decrease by $0.10 \mathrm{~g} / \mathrm{L}$ of the GrSC. This decrease of the GrSC can be related with the retarding effect of altitudinal increasing on grapes maturation, highlighted by previous studies (Calame et al., 1977). Linearity of the altitudinal distribution of the GrSC is disrupted by the ASD variation that generates local variation of GrSC regardless of the altitude. GrSC variability is characterized by an average of $16.9 \%$ of the spread index, value which is comparable with the one provided by other authors (Bramley, 2005).

The map of GrSC allowed revealing, as practical utility, the spatial distribution of wine types that can be obtained within the area. Differentiation of wine types in relation to altitude has been highlighted for other wine growing regions too (Shanmuganathan, 2010). Also, classification of spatial distribution of grapes quality parameters in order to delineate areas of wine quality within the vineyards is already practiced (ASAE, 2007). In our study two areas with different potential for wine production were delineated: an area situated below $150 \mathrm{~m}$ asl. where the GrSC records high values which ensure DOC-CT wines obtaining; and an area ranging between 150 and $250 \mathrm{~m}$ asl. where the GrSC records lower values which ensure DOC-CMD wines obtaining. 
Since vineyards' climate is specific, temporally stable (Jones et al., 2005) and less affected by vintage climate, its influence on grapes quality parameters should generate rather similar consequences from one year to another. Thus, the map of GrSC and also the map of wine types that it provides should present a certain spatio-temporal stability. By knowing the regression coefficients which characterize the relationship between climate variables and GrSC, the impact of their annual variation on wine production zones can be predicted. However, the lack of information on yield quality over several vintages prevents us from considering the study's outcomes as indisputable. Moreover, accurate setting of the spatial distribution of GrSC would require the representation of pedological and biological factors influence. Yet, given the significance of the statistical correlations between climate and GrSC, the map of spatial distribution of the GrSC for the 2011 vintage and the map of obtainable wine types, based on it, can be considered as guidance tools for site specific management within the Huşi wine growing region.

\section{Conclusions}

The study provides new information on the factors that determine the spatial variation of grapes sugar content within vineyards. Although it is a spatially and temporally variable parameter, grapes sugar content shows significant correlations with climate variables specific to vineyards and with the climatic suitability for wine production they generate. Knowing these correlations allows revealing patterns that determine spatial distribution of grapes sugar content within the vineyard. In the case of the Huși wine growing region, based on the significant correlation of GrSC with climate suitability $(r=0.68)$, the map of GrSC for the 2011 vintage and the map of wine types that can be obtained were drawn up. The two maps reveal a coherent pattern of spatial distribution of grapes sugar content at vineyard scale, significantly correlated with terrain altitude. Such maps can be improved by integrating the influence of technological, biological and pedological factors on GrSC and can be used as tools for vineyard site-specific management. Based on grapes sugar content of a single vintage, this study did not allow the assessment of spatiotemporal stability of the obtained pattern of GrSC spatial distribution. By mapping the grapes sugar content for many years and analyzing its correlations with other factors which determine it, a clear pattern of GrSC spatial distribution within the Huşi wine growing region can be achieved.

\section{References}

Agelet-Fernández J, Martínez-Casasnovas JA, Arnó J (2009). Selective harvesting zones from remote sensing images and yield data and relation to grape quality parameters for precision viticulture. EFITA Conference 709-715.

ASAE (2007). Interpolation of wine grape quality indicators (Anthocyanin and Brix) and development of differential harvest attachment. ASAE Annual Meeting 071097. doi:10.13031/2013.22971.

Bramley RGV (2005). Understanding variability in winegrape production systems. 2. Within vineyard variation in quality over several vintages. Aust J Grape Wine Res 11(1):33-42.
Calame F, Rochaix M, Simon JL (1977). Observations phénologiques et mesures bioclimatiques dans plusieurs sites viticoles valaisans à différentes altitudes en vue de la délimitation de l'aire viticole. Bulletin del'OIV 50-559:601-616.

Champagnol F (1984). Eléments de physiologie de la vigne et de viticulture générale. Champagnol $\mathrm{F}(\mathrm{Ed})$, Montpellier, $351 \mathrm{p}$.

FAO - Food and Agriculture Organization of the United Nations (2003). FAOCLIM-2. World-wide Agroclimatic Database v.2.02, FAO/SDRN.

Galet P (1993). Precis de viticulture. Charles Dehan, Montpellier.

Huglin P (1978). Nouveau mode d'évaluation des possibilités héliothermiques d'un milieu viticole. CRAcad Agric Fr 64(13):11171126.

Huglin P (1986). Biologie et écologie de la vigne. Payot (Ed), Lausanne, $372 \mathrm{p}$.

Huglin P, Balthazard J (1976). Données relatives a linfluence du rendement sur le taux des sucres des raisins. Connaiss Vigne Vin 10:175-191.

Irimia L, Patriche CV, Quenol H (2011). GIS applications in viticulture. The spatial distribution of climatic suitability for grapegrowing in Husi wine-growing centre (Romania). Cercet Agron Mold 3(147):75-87.

Irimia L, Patriche CV, Quenol H (2014). Analysis of viticultural potential and deliniation of homogeneous viticultural zones in a temperate climate region of Romania.J Int Sci Vigne Vin 48(3):145-167.

Jackson DI, Lombard PB (1993). Environmental and management practices affecting grape composition and wine quality - a review. Am JEnol Vitic 44(4):409-430.

Jones GV, White MA, Cooper OR, Storchmann K (2005). Climate change and global wine quality. Clim Change 73(3):319-343.

Kottek M, Grieser J, Beck C, RudolfB, Rubel F (2006). Worldmap of the Köppen-Geiger climate classification updated. Meteorol Z 15:259263.

Lamb DW, Weedon MM, Bramley RGV (2003). Using remote sensing to map grape phenolics and colour at harvest in a Cabernet Sauvignon vineyard: timing observations against vine phenology and optimising image resolution. Aust J Grape Wine Res 10:46-54.

OIV (1990). Recueil des méthodes internationales d'analyse des vins et des moûts. 368 p. Office International de la Vigne et du Vin. Paris.

ONIV (2015). Specification for the production and marketing of wine with designation of Huşi origin. http://www.oniv.ro/att_view.php?id=433 (in Romanian, accessedin 4October 2014).

Patriche CV (2007). Aspects concerning the spatialization of radiation balance components. In: Spatial Interpolation for Climate Data, pp. 121-138. The Use of GIS in Climatology and Meteorology. Dobesch H, Dumolard P, Dyras I (Eds), WileyISTE.

Santos AO, Wample RL, Sachidhanantham S, Kaye O (2012). Grape quality mapping for vineyard differential harvesting. Braz Arch Biol Technol 55(2):193-204.

Sethuramasamyraja B, Sachidhanantham S, Yen M, Wample R (2007). Interpolation of wine grape quality indicators (Anthocyanin and Brix) and development of differential harvest attachment. In: Proceedings of the 2007 ASABE Annual Meeting, 
258

Minneapolis, 115-120.

Shanmuganathan S (2010). Viticultural Zoning for the Identification and Characterisation of New Zealand "Terroirs" Using Cartographic Data. Proceedings of GeoCart'2010 and ICA Symposium on Cartography, New Zealand Cartographic Society Inc.

Teodorescu S, Popa AI, Sandu G (1987). Oenoclimate of Romania (in Romanian). Ed. Ştiinţifică şi Enciclopedică, Bucureşti.

Tisseyre B, Mazzoni C, Fonta H (2008). Within-field temporal stability of some parameters in viticulture: Potential toward a site specific management. J Int Sci Vigne Vin 42:27-39.

Tisseyre B, Taylor J (2005). An overview of methodologies and technologies for implementing precision agriculture in viticulture. XII Congresso Brasileiro de Viticultura e Enologia Anais 45-54.
Trought MCT, Bramley RGV (2011). Vineyard variability in Marlborough, New Zealand: Characterizing spatial and temporal changes in fruit composition and juice quality in the vineyard. Australian Journal of Grape and Wine Research 17(1):79-89.

Van Leeuwen C (2010). Terroir: the effect of the physical environment on vine growth, grape ripening and wine sensory attributes, pp. 273315. In: Reynolds AG (Ed). Managing wine quality. Viticulture and wine quality. Woodhead Publishing, Cambridge.

Wold S, Trygg J, Berglund A, Antti H (2001). Some recent developments in PLS modeling. Chem Intelligent Lab Systems 58:131-150.

Workman Jr J, Burns DA (2001). Comercial NIR instrumentation. In: Burns D, Ciurczak EW (Eds). Handbook of Near-Infrared analysis. pp. 53-70. New York: Marcel Dekker. 